\title{
Molecular Detection of Bartonella Species in Rodents Residing in Urban and Suburban Areas of Central Thailand
}

\author{
Phirabhat Saengsawang ${ }^{1}\left(\mathbb{D}\right.$, Serge Morand ${ }^{2,3} \mathbb{D}$, Marc Desquesnes ${ }^{4,5} \mathbb{D}$, Sarawut Yangtara ${ }^{6}$ \\ and Tawin Inpankaew $7, *$ (D)
}

1 Akkhraratchakumari Veterinary College, Walailak University, Nakhon Si Thammarat 80161, Thailand; phirabhat.s@gmail.com or phirabhat.sa@wu.ac.th

2 CNRS ISEM-CIRAD-ASTRE, Montpellier University, 34090 Montpellier, France; serge.morand@umontpellier.fr

3 Faculty of Veterinary Technology, Kasetsart University, Bangkok 10900, Thailand

4 InterTryp, Université de Montpellier CIRAD-IRD, 34090 Montpellier, France; marc.desquesnes@cirad.fr

5 Ecole Nationale Vétérinaire de Toulouse (ENVT), 31300 Toulouse, France

6 Department of Companion Animal Clinical Science, Faculty of Veterinary Medicine, Kasetsart University, Bangkok 10900, Thailand; great_vt14@hotmail.com

7 Department of Parasitology, Faculty of Veterinary Medicine, Kasetsart University, Bangkok 10900, Thailand

* Correspondence: tawin.i@ku.th

check for updates

Citation: Saengsawang, P.; Morand, S.; Desquesnes, M.; Yangtara, S.; Inpankaew, T. Molecular Detection of Bartonella Species in Rodents Residing in Urban and Suburban Areas of Central Thailand. Microorganisms 2021, 9, 2588. https://doi.org/ 10.3390/microorganisms 9122588

Academic Editor: Merle

Margarete Böhmer

Received: 20 November 2021

Accepted: 13 December 2021

Published: 15 December 2021

Publisher's Note: MDPI stays neutral with regard to jurisdictional claims in published maps and institutional affiliations.

Copyright: (c) 2021 by the authors. Licensee MDPI, Basel, Switzerland. This article is an open access article distributed under the terms and conditions of the Creative Commons Attribution (CC BY) license (https:/ / creativecommons.org/licenses/by/ $4.0 /)$.

\begin{abstract}
Bartonella spp. are Gram-negative zoonotic bacteria transmitted to humans via various blood-sucking arthropods. Rodents have been identified as reservoir hosts of several zoonotic pathogens, including Bartonella spp. In Thailand, studies of Bartonella spp. in rodents from urban areas are limited; thus, a study in this area is necessary. The objectives of this study were to detect Bartonella spp. in rodents in Thailand and to compare the species' distribution across different areas. In total, 70 blood samples from rodents in urban and suburban areas were tested for Bartonella spp. using a conventional polymerase chain reaction that targeted the citrate synthase $(g l t A)$ gene. All Bartonella-positive sequences were analyzed using polymorphism in order to build a phylogenetic tree. Approximately $38 \%$ of the rodents studied contained Bartonella DNA. Both Rattus exulans (Pacific rat) and R. tanezumi (Asian house rat) contained Bartonella spp. Four species of Bartonella were detected in blood samples: B. tribocorum, B. phoceensis, B. grahamii, and B. rattimassiliensis. In addition, eight Pacific rats contained the B. kosoyi-B. tribocorum complex. Bartonella phoceensis and B. tribocorum-B. kosoyi complexes were found in a specific habitat $(p<0.05)$. Interestingly, only seven haplotypes were identified in the sequences analyzed, and only haplotype A was found in both rodent species. Finally, a monitoring program for zoonotic Bartonella infection, especially the B. kosoyi-B. tribocorum complex, B. phoceensis, B. grahamii, and B. rattimassiliensis should be established, especially in high-risk areas.
\end{abstract}

Keywords: Bartonella; Rattus; zoonosis; diversity; gltA; Thailand

\section{Introduction}

Bartonella spp. are Gram-negative intraerythrocytic bacteria [1] that have been rearranged into the alpha-proteobacteria [2] and are transmitted by blood-sucking arthropods [3]. Several species of Bartonella have been confirmed as zoonotic pathogens, including B. henselae, B. clarridgeiae, B. elizabethae, B. grahamii, B. koehlerae, B. quintana, B. washoensis, and B. vinsonii [4]. New members of the genus Bartonella are being found continuously [5], and more than 35 species have had their whole-genome sequences identified. To date, around 6 of the 20 rodent-adapted Bartonella spp. are zoonotic pathogens [6] that are important in medical and veterinary medicine [7]. Several types of animals are confirmed as hosts transmitting Bartonella spp., including cats [4,8], dogs [1,4], cattle [9,10], and rodents [11,12]. Furthermore, Bartonella spp. have been detected in rodents in several continents, including Asia [13], Africa [14], Europe [7], Americas [12,15], and Australia [16]. 
Some rodents have been suspected of being a source of zoonotic pathogens transmitted to humans [17], such as Rickettsia spp., Leptospira spp., Coxiella burnetii, Orientia tsutsugamushi, and Bartonella spp. [18]. From a public health viewpoint, there could be an increase in human cases due to infection by rodent-borne Bartonella spp. from outdoor activities [6] and other indirect contact. Changing land use and the sharing of habitat among rodents, animals, and humans have been identified as causes of zoonotic infection $[19,20]$. Several Bartonella spp. that have been associated with specific species of rodent could be the causative agents of Bartonella-related diseases in humans, such as endocarditis, lymphadenopathy, and some neurological abnormalities [11,21].

Bartonella infection in rodents frequently shows persistent and subclinical bacteremia $[6,18]$. Approximately 90 species of rodent have Bartonella spp. [18] variants in abundance, and at least 22 species of Bartonella have been found in rodents [6]. Bartonella doshiae [22], B. elizabethae [23], B. grahamii [24], B. rochalimae [25], B. tamiae [26], B. tribocorum [27], B. vinsonii subsp. arupensis [28], and B. washoensis [29] have been reported as the main Bartonella spp. found in rodents that cause human infections. Compared with other mammals, the different level of infection and high genetic diversity of Bartonella spp. in rodents has been noted [5].

In 2010, Thai febrile patients showed evidence of zoonotic species of Bartonella based on a molecular detection [26,30]. In Thailand, the study of zoonotic Bartonella spp. has been mainly conducted in companion animals [31-33] and their ectoparasites [34]; however, studies involving rodents are limited, and additional studies in urban areas are needed [35]. With regard to the Thai government's "One Health" approach to humans, animals, and vectors, further studies on Bartonella are also necessary [34]. The current study therefore aims to survey the prevalence of Bartonella infection in rodents and to compare the species of Bartonella in areas of different characteristics (urban and suburban environments).

\section{Materials and Methods}

\subsection{Sample Size}

The sample size was calculated using an equation for the infinite population proportion [36] and a prevalence ( $p$ ), taken from a previous study in Thailand [19]. Bangkok and Nakhon Sawan provinces were defined as urban and suburban areas, respectively. Hence, the previous proportion ( $p=4.38 \%$ ) was re-calculated from data on settlement and rain-fed areas derived from the previous study. For the sample size calculation, the maximum tolerated error $(d)$ and alpha $(\alpha)$ were set at $5 \%$. In total, the calculated sample size was 65 rodents based on the following equation:

$$
n=\frac{Z_{1-\frac{\alpha}{2}}^{2} \times p \times(1-p)}{d^{2}}
$$

\subsection{Sample Collection}

The sampling was approved by the Kasetsart University Institutional Animal Care and Use Committee, Bangkok, Thailand, under the Ethical Review Board of the Office of the National Research Council of Thailand (NRCT; approval ID: ACKU63-VET-048). This study was a cross-sectional survey of rodents trapped from fields in two provinces (Bangkok and Nakhon Sawan), as shown in Figure 1. The rodents were trapped between 2011 and 2013. All trapped rodents were classified based on external morphological characteristics. Three milliliters of blood were collected from each sample using aseptic cardiac puncture and were kept in a sterile EDTA tube. Euthanasia was conducted using chloroform inhalation after blood collection. All blood samples were stored at $-20{ }^{\circ} \mathrm{C}$ until DNA extraction. Additionally, the standard procedures applied by the laboratory in this study followed the verification of the Institutional Biosafety Committee (IBC), Faculty of Veterinary Medicine, Kasetsart University. 


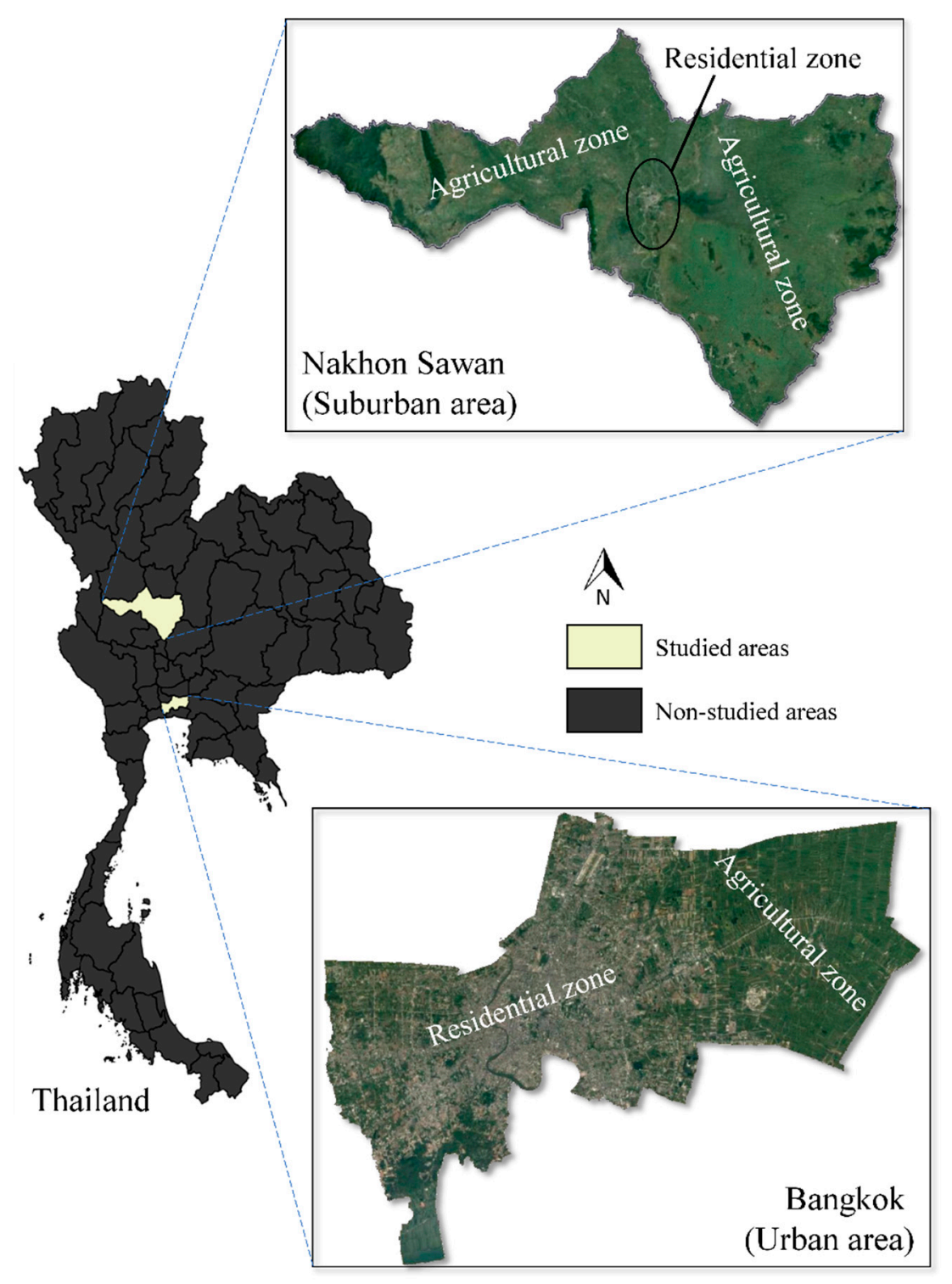

Figure 1. Sample collection sites and their geographic characteristics.

\subsection{DNA Extraction from Whole Blood}

Two hundred microliters of whole blood was extracted for genomic DNA testing using a commercial extraction kit (FavoPrep ${ }^{\mathrm{TM}}$ Blood DNA Extraction Mini Kit, Favorgen Biotech Corporation, Pingtung, Taiwan). The extraction protocol was performed according to the manufacturer's instructions, and $100 \mu \mathrm{L}$ of nuclease-free water was used as the elution solution. The extracted DNA was kept at $-20^{\circ} \mathrm{C}$ until a polymerase chain reaction (PCR) was performed.

\subsection{Bartonella Detection Using Polymerase Chain Reaction}

Bartonella spp. were detected using conventional PCR. BhCS.781p (5'-GGGGACCAGC TCATGGTGG-3') and BhCS.1137n (5'-AATGCAAAAAGAACAGTAAACA-3') were used to target the citrate synthase ( $g l t A$ ) gene of Bartonella spp. [37]. The targeted $379 \mathrm{bp}$ fragment was suspected to be a Bartonella-positive blood sample, and the conditions of amplification were controlled using a thermocycler (Mastercycler ${ }^{\circledR}$ Nexus Gradient, Eppendorf, Hamburg, Germany). In total, $25 \mu \mathrm{L}$ of PCR mixture (0.2 mM of each dNTPs, $1 \mathrm{X}$ of Taq reaction buffer with $\mathrm{MgSO}_{4}, 4 \mathrm{pmol} / \mu \mathrm{L}$ of each primer, $0.04 \mathrm{U} / \mu \mathrm{L}$ of Taq DNA polymerase, $0.8 \%$ of dimethyl sulfoxide, and $3 \mu \mathrm{L}$ of DNA template) were run for PCR detection and commercial Taq DNA polymerase was used (Taq DNA Polymerase, Applied Biological 
Materials (ABM ${ }^{\circledR}$ Inc., Richmond, BC, Canada). The running of PCR for BhCS.781p and BhCS.1137n was performed as follows: $5 \mathrm{~min}$ at $95^{\circ} \mathrm{C}$ for initial denaturation, 35 repeated cycles of denaturation $\left(95^{\circ} \mathrm{C}, 20 \mathrm{~s}\right)$, annealing $\left(51^{\circ} \mathrm{C}, 30 \mathrm{~s}\right)$, and elongation $\left(72{ }^{\circ} \mathrm{C}, 2 \mathrm{~min}\right)$. The last elongation was conducted at $72{ }^{\circ} \mathrm{C}$ for $5 \mathrm{~min}$. Bartonella henselae strain Houston-1 DNA and nuclease-free water were used as the positive and negative controls, respectively. The amplified products were kept at $4{ }^{\circ} \mathrm{C}$ until gel electrophoresis.

\subsection{Gel Electrophoresis and Purification}

Twenty microliters of the amplified product was run in 1.5\% agarose gel under a $0.5 \mathrm{X}$ tris-acetate EDTA (TAE) buffer for $45 \mathrm{~min}$ at $100 \mathrm{~V}$, and UltraPower ${ }^{\mathrm{TM}}$ Nucleic Acid Stain (BioTeke Corporation, Wuxi, China) was used for DNA staining. DNA visualization was performed using an ultraviolet illuminator (Gel Doc InGenius, SYNGENE, Frederick, MD, USA) and a 100-bp DNA ladder was used as the DNA size marker (Enzynomics, Daejeon, South Korea). The 379 bp band was cut and purified using a DNA purification kit (Gel and PCR Purification System, BioFACTTM, Daejeon, South Korea). The running protocol followed the manufacturer's instructions. Forty microliters of eluted purified DNA fragments were sent to a commercial sequencing unit using Sanger's sequencing technology (Macrogen ${ }^{\circledR}$, Seoul, Korea).

\subsection{Analysis of DNA Sequence}

The obtained DNA sequences were trimmed using the Chromatogram Explorer Lite version 5.0.2 software (http:/ / www.dnabaser.com, accessed on 20 November 2021) under the default low-quality end trimming conditions ( $75 \%$ of good bases, 18 bases of window length, and 25 quality value (QV) of good base). The trimmed DNA chromatograms were edited using the SnapGene ${ }^{\circledR}$ Viewer version 5.3.2 software (https:/ / www.snapgene.com/ snapgene-viewer, accessed on 20 November 2021) and analyzed using BLASTn (https: / / blast.ncbi.nlm.nih.gov / Blast.cgi, accessed on 20 November 2021). A phylogenetic tree was constructed using the neighbor-joining method based on a proper substitution model with 1000 bootstrapping replications in the Molecular Evolutionary Genetics Analysis (MEGA) version X software (https: / / www.megasoftware.net, accessed on 20 November 2021). Bartonella positive sequences were analyzed for polymorphism based on the number of variable sites (VS), the proportion of $G+C$ content (GC), the number of haplotypes (h), the average number of nucleotide differences $(k)$, haplotype diversity $(\mathrm{Hd})$, and nucleotide diversity $(\pi)$ using the DNA Sequence Polymorphism (DnaSP) version 6.12.03 software (http:/ / www.ub.edu/dnasp, accessed on 20 November 2021). Then, the sequences were analyzed based on a median-joining network using the Population Analysis with Reticulate Trees (PopART) version 1.7 software (http:/ / popart.otago.ac.nz/index.shtml, accessed on 20 November 2021) with the default setting (epsilon $=0$ ). All Bartonella-matched sequences were submitted to GenBank with accession numbers: OK381826-OK381850.

\subsection{Statistical Analysis}

The data were presented using descriptive statistics (mean and standard deviation). Prevalence was calculated, and the Wilson score interval method was used to estimate the $95 \%$ confidence interval of prevalence [38]. Associated factors were analyzed using Chi-square or Fisher's exact test. All statistical analyses were performed using the $95 \%$ confidence interval $(\mathrm{CI})$, and $p<0.05$ was considered the significant level. All statistical analyses were performed using the R programming language version 4.0.2 [39].

\section{Results}

\subsection{Bartonella Species in Rodents}

In total, 70 rodents were trapped in the two different environments: 30 Rattus exulans in urban (Bangkok) and 40 R. tanezumi in suburban (Nakhon Sawan). Of these, 27 (38.57\%; 95\% CI $=28.05-50.28 \%$ ) had Bartonella DNA in their blood samples. Overall, no associated factors of Bartonella infection were identified in the rodents (Table 1). 
Table 1. Factors associated with Bartonella infection in rodents.

\begin{tabular}{ccccc}
\hline & Factor & Total & Positive & $p$-Value \\
\hline \multirow{2}{*}{ Area } & Urban (Bangkok) & 30 & 13 & \multirow{2}{*}{$0.65^{\text {a }}$} \\
& Suburban (Nakhon Sawan) & 40 & 14 & \multirow{2}{*}{$0.65^{\text {a }}$} \\
\hline \multirow{2}{*}{ Rodent $^{c}$} & Pacific rat (Rattus exulans) & 30 & 13 & \multirow{2}{*}{$0.19^{\mathrm{b}}$} \\
& Asian house rat (Rattus tanezumi) & 40 & 14 & 20 \\
\multirow{2}{*}{ Season } & Warm & 58 & 7 & 12 \\
& Cool &
\end{tabular}

a Chi-square test; ${ }^{\mathrm{b}}$ Fisher's exact test; ${ }^{\mathrm{c}}$ All R. exulans found in Bangkok and all R. tanezumi found in Nakhon Sawan.

Of the Pacific rat blood samples, 13 (43.33\%; 95\% CI = 27.38-60.80\%) were positive for Bartonella gltA fragments. Additionally, 14 Asian house rats (35.00\%: 95\% CI $=22.13-50.49 \%)$ had a glt $A$ fragment of Bartonella spp. The BLAST results revealed a B. kosoyi-B. tribocorum complex $(11.43 \%$; $95 \% \mathrm{CI}=5.91-20.96 \%)$ and $B$. phoceensis $(20.00 \% \%$; $95 \% \mathrm{CI}=12.30-30.82 \%)$. All BLASTn results are presented in Table 2.

Table 2. Detected species of Bartonella based on gltA sequences.

\begin{tabular}{|c|c|c|c|c|}
\hline Rodent & Bartonella spp. & $\mathbf{n}$ & 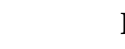 & nce \\
\hline \multirow{5}{*}{$\begin{array}{l}\text { R. exulans } \\
\quad(n=30)\end{array}$} & B. kosoyi-B. tribocorum & 8 & $26.67 \%$ & $14.18-44.45 \%$ \\
\hline & B. phoceensis & 1 & $3.33 \%$ & $0.59-16.67 \%$ \\
\hline & B. grahamii & 1 & $3.33 \%$ & $0.59-16.67 \%$ \\
\hline & B. tribocorum & 1 & $3.33 \%$ & $0.59-16.67 \%$ \\
\hline & Bartonella spp. & 2 & $6.67 \%$ & $1.85-21.32 \%$ \\
\hline \multirow{2}{*}{$\begin{array}{l}\text { R. tanezumi } \\
\quad(n=40)\end{array}$} & B. phoceensis & 13 & $32.50 \%$ & $20.08-47.98 \%$ \\
\hline & B. rattimassiliensis & 1 & $2.50 \%$ & $0.44-12.88 \%$ \\
\hline
\end{tabular}

Eight sequences from $R$. exulans closely matched the B. kosoyi sequences (\% identity $=99.36-100 \%)$ isolated from black rats (R. rattus) (CP031843) and B. tribocorum sequences (\% identity $=99.36-100 \%)$ isolated from humans (HG969192). Surprisingly, the results of BLASTn for both B. kosoyi and B. tribocorum had similarity percentages; however, there were differences in non-compatible positions. Hence, these sequences $(n=8)$ were called a $B$. kosoyi-B. tribocorum complex. Interestingly, 14 sequences from $R$. tanezumi and $R$. exulans were similar to the $B$. phoceensis sequence ( $\%$ identity $=97.94-100 \%$ ) isolated from brown rats ( $R$. norvegicus) (AY515126). In more minor findings, two other sequences (one from an Asian house rat and the other from a Pacific rat) matched B. rattimassiliensis $(\%$ identity $=100 \%$; JX158359) and B. grahamii (\%identity $=100 \%$; GU056195), respectively. Comparing the two species (B. phoceensis and the B. kosoyi-B. tribocorum complex) and areas (Bangkok and Nakhon Sawan), there were significant differences in the proportion of Bartonella spp. Overall, B. phoceensis was found mostly in Nakhon Sawan, while the B. kosoyi-B. tribocorum complex was found only in Bangkok.

\subsection{Phylogenetic Tree and Polymorphism Based on gltA Sequences}

Sequencing of the glt $A$ fragments identified five species of Bartonella; the phylogenetic tree of the Bartonella positive sequences is presented in Figure 2. The tree had two main species complexes, consisting of a B. phoceensis complex $(n=14)$ and a B. kosoyi-B. tribocorum complex $(n=9)$. However, two sequences in the $B$. phoceensis complex were separate from the others. In the same way, in the B. tribocorum-B. kosoyi complex, one sequence was separate from the others. The polymorphism information of the partial glt $A$ sequences that matched the B. kosoyi-B. tribocorum complex and B. phoceensis is presented in Table 3. Additionally, the variable position (singleton and parsimony-informative sites) is presented in Table 4. For these two complexes, the median-joining network is illustrated in Figure 3. Seven different haplotypes among $25 \mathrm{glt} A$ sequences ( $n=13$ for $R$. exulans and $n=14$ for $R$. tanezumi) showed $\pi=0.06471 \pm 0.00617, \mathrm{Hd}=0.687 \pm 0.071$, and $k=19.61$. Only haplotype A (12 sequences) 
showed different species of rodent that had B. phoceensis. However, other haplotypes (B-G) revealed specific Bartonella spp. Comparing the with and without reference sequences, those that matched B. kosoyi and B. tribocorum were clearly different from the references (CP031843 and HG969192). In contrast, the diversity difference between the with and without reference groups in B. phoceensis was not different from the previous finding.

Table 3. Details of polymorphism of B. kosoyi-B. tribocorum and B. phoceensis gltA fragments.

\begin{tabular}{|c|c|c|c|c|c|c|c|}
\hline Bartonella spp. & $\mathbf{N}$ & VS & GC & $\mathbf{h}$ & $\mathbf{k}$ & $\mathbf{H d} \pm \mathbf{S D}$ & $\pi \pm \mathrm{SD}$ \\
\hline B. kosoyi ${ }^{\text {a }}$ & 8 & 0 & 0.337 & 1 & 0.00 & 0.00 & 0.00 \\
\hline B. kosoyi b & 9 & 1 & 0.337 & 2 & 0.22 & $0.222 \pm 0.166$ & $0.00073 \pm 0.00055$ \\
\hline B. tribocorum ${ }^{\text {a }}$ & 9 & 5 & 0.336 & 2 & 1.11 & $0.222 \pm 0.166$ & $0.00367 \pm 0.00274$ \\
\hline B. tribocorum ${ }^{\mathrm{b}}$ & 10 & 5 & 0.336 & 3 & 1.16 & $0.378 \pm 0.181$ & $0.00381 \pm 0.00241$ \\
\hline B. phoceensis $^{\text {a }}$ & 14 & 8 & 0.349 & 3 & 1.26 & $0.275 \pm 0.148$ & $0.00378 \pm 0.00247$ \\
\hline B. phoceensis b & 15 & 8 & 0.349 & 3 & 1.18 & $0.257 \pm 0.142$ & $0.00354 \pm 0.00234$ \\
\hline
\end{tabular}

${ }^{a}$ compared among sequences of this study; ${ }^{b}$ compared among sequences of this study and reference (match) sequence; $n=$ number of analyzed sequences; VS = number of variable sites; $\mathrm{GC}=$ proportion of $\mathrm{G}+\mathrm{C}$ content; $\mathrm{h}=$ number of haplotypes; $k=$ average number of nucleotide difference; $\mathrm{Hd}=$ haplotype diversity; $\pi$ = nucleotide diversity; $\mathrm{SD}=$ standard deviation.

Table 4. Details of the variable positions of each Bartonella-positive group.

\begin{tabular}{|c|c|c|c|c|c|c|c|c|c|c|c|}
\hline Species & Sequence & Accession Number & $\begin{array}{l}\text { Length } \\
\text { (bp) }\end{array}$ & & & & Variab & osition & & & \\
\hline B. kosoyi & $\begin{array}{l}\text { This study } \\
\text { Reference }\end{array}$ & $\begin{array}{c}\text { OK381843-50 } \\
\text { CP031843 }\end{array}$ & 337 & $\begin{array}{c}34^{\mathrm{a}} \\
\mathrm{G} \rightarrow \mathrm{T}\end{array}$ & & & & & & & \\
\hline B. tribocorum & $\begin{array}{l}\text { This study } \\
\text { Reference }\end{array}$ & $\begin{array}{c}\text { OK381826, 43-50 } \\
\text { HG969192 }\end{array}$ & 337 & $\begin{array}{l}115^{b} \\
C \rightarrow T\end{array}$ & $\begin{array}{l}220^{\mathrm{a}} \\
\mathrm{G} \rightarrow \mathrm{T}\end{array}$ & $\begin{array}{l}221^{\mathrm{a}} \\
\mathrm{C} \rightarrow \mathrm{T}\end{array}$ & $\begin{array}{l}271^{\mathrm{a}} \\
\mathrm{C} \rightarrow \mathrm{T}\end{array}$ & $\begin{array}{l}286^{\mathrm{a}} \\
\mathrm{G} \rightarrow \mathrm{A}\end{array}$ & & & \\
\hline B. phoceensis & $\begin{array}{l}\text { This study } \\
\text { Reference }\end{array}$ & $\begin{array}{c}\text { OK381828-41 } \\
\text { AY515126 }\end{array}$ & 341 & $\begin{array}{c}47^{\mathrm{a}} \\
\mathrm{C} \rightarrow \mathrm{T}\end{array}$ & $\begin{array}{c}95^{\mathrm{a}} \\
\mathrm{C} \rightarrow \mathrm{T}\end{array}$ & $\begin{array}{l}104^{\mathrm{a}} \\
\mathrm{T} \rightarrow \mathrm{C}\end{array}$ & $\begin{array}{l}197^{b} \\
G \rightarrow T\end{array}$ & $\begin{array}{l}207^{\mathrm{a}} \\
\mathrm{G} \rightarrow \mathrm{A}\end{array}$ & $\begin{array}{l}269^{a} \\
C \rightarrow T\end{array}$ & $\begin{array}{l}300^{\mathrm{a}} \\
\mathrm{T} \rightarrow \mathrm{C}\end{array}$ & $\begin{array}{l}314^{\mathrm{a}} \\
\mathrm{C} \rightarrow \mathrm{T}\end{array}$ \\
\hline
\end{tabular}

${ }^{\text {a }}$ Singleton variable site; ${ }^{\mathrm{b}}$ Parsimony informative site. 


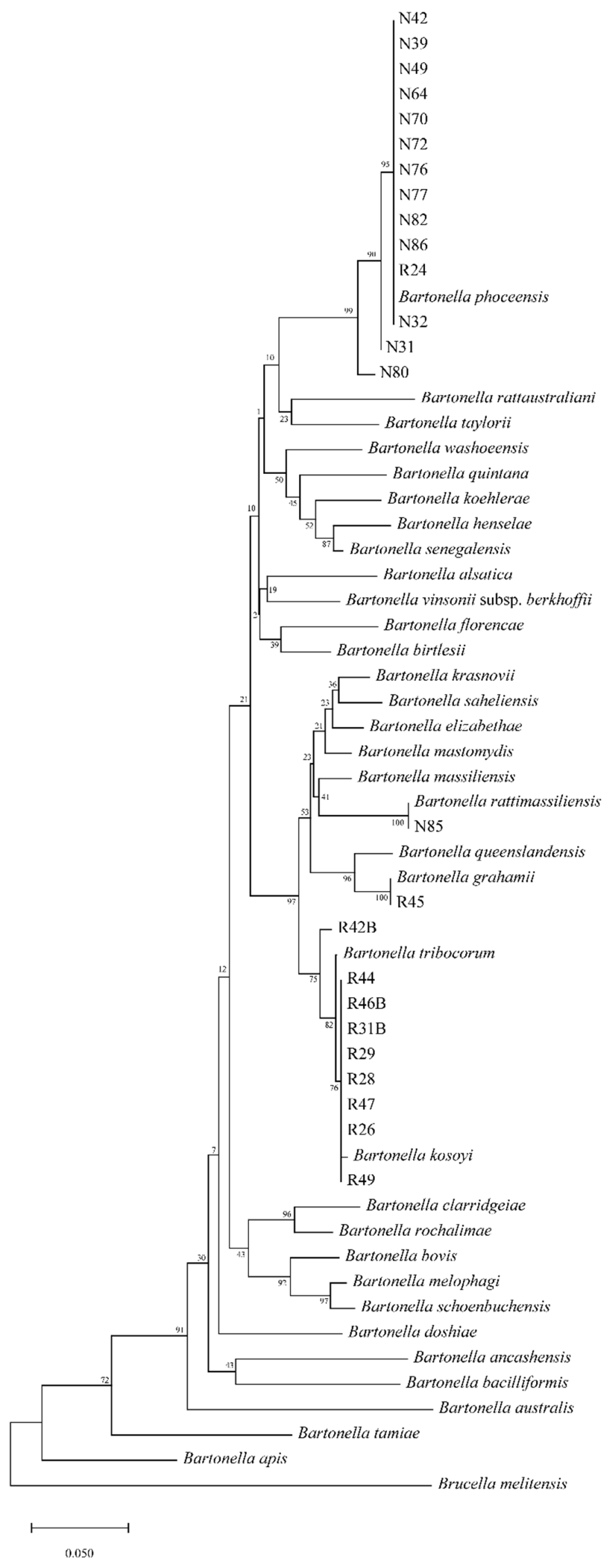

Figure 2. Phylogenetic tree of Bartonella gltA sequences obtained from rodents in this study. 


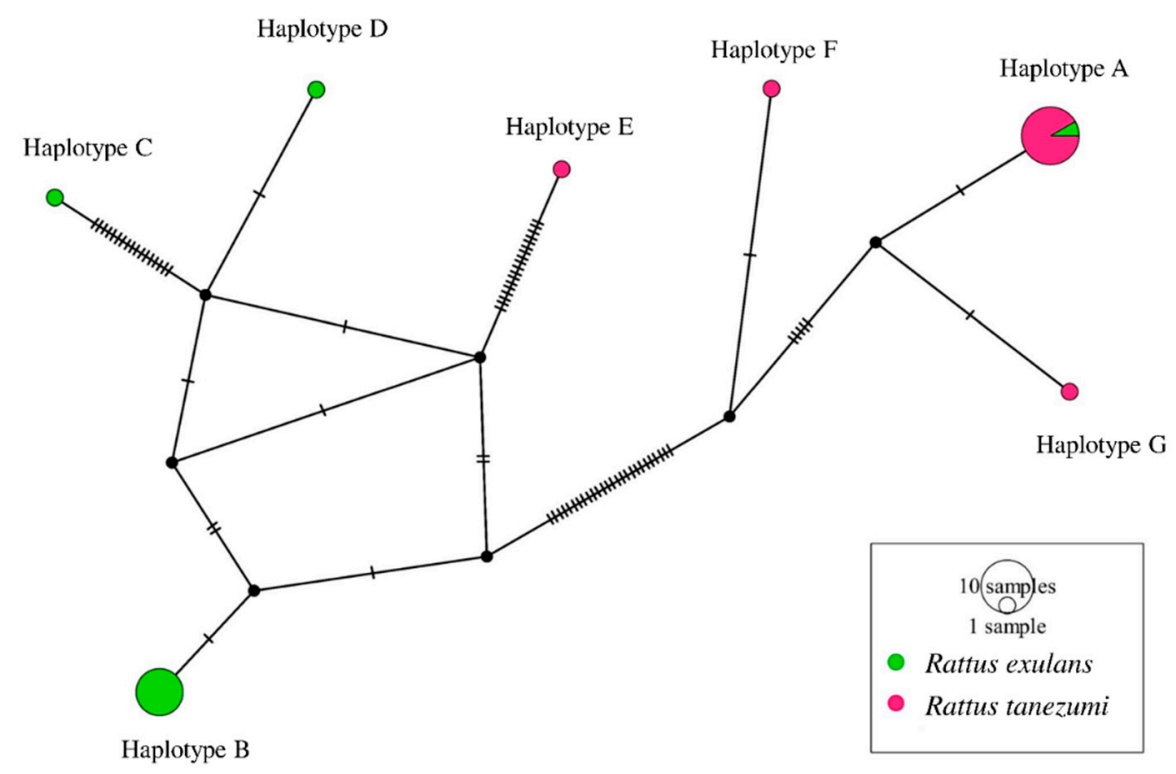

Figure 3. Median-joining network of glt $A$ haplotypes from two different rodent species in Thailand.

\section{Discussion}

In this study, the trapped rodents belonged to two species: R. exulans and R. tanezumi. In Thailand, various species of rodent were identified, including Rattus spp., Bandicota spp., Leopoldamys spp., Mus spp., and Niviventer spp. [40]. Rattus spp. was found in suburban areas in the current study. Of these, R. tanezumi and R. exulans were reported as major species of Rattus in Thailand [40]. Interestingly, R. tanezumi is a synanthropic rodent species mostly found in suburban environments, including residential and agricultural areas [41]. In urban areas, some species of Rattus were also reported such as R. norvegicus and $R$. rattus [35]. Due to the increase in human-rodent contact, attention has been focused on various emerging diseases caused by novel pathogens [42]. Several rodent-borne pathogens can cause various human diseases, such as hantavirus, Borrelia spp., Toxoplasma gondii, Yersinia pestis, Bartonella spp., Leptospira spp., and Coxiella burnetii [43].

Many rodents in the current study had Bartonella spp. in their blood samples. Importantly, rodents have been mentioned as a major source of Bartonella infection in humans [44]. Rodent-borne Bartonella spp. have been discovered globally, and the rodent-adapted Bartonella spp. have high diversity [6]. Partial sequences of the glt $A$ gene revealed five species of Bartonella: B. tribocorum, B kosoyi, B. phoceensis, B. grahamii, and B. rattimassiliensis. Of these, three species have been reported as human pathogens [30,45]. The overall prevalence of Bartonella spp. in the current study differed from other studies in Malaysia [46] and China [13]; however, the prevalence of a study in Chile [12] was similar to the prevalence of the current study. Most studies in Thailand have reported Bartonella spp. being frequently isolated from $R$. rattus $[20,47,48]$. The prevalence of Bartonella spp. in $R$. tanezumi in the current study was similar to that found in a study in Singapore [49]; however, it contrasts with many other studies $[17,50,51]$. Bartonella rattimassiliensis and B. phoceensis were positive in R. tanezumi blood samples, which is a result similar to those of studies in Malaysia [46], Indonesia [52], Vietnam [50], and Singapore [49]. In addition, two zoonotic Bartonella spp. (B. tribocorum and B. grahamii) were detected in R. exulans blood samples, which was similar to other studies in Thailand $[17,48,53]$. Nevertheless, in the current study, the prevalence of Bartonella spp. in R. exulans differed from other studies [17,47-50,53-55]. Particularly in urban habitats, Bartonella infection risk in humans increases from contact among humans, rodents, and ectoparasites [56]. In Thailand, rodent lice and fleas have been reported to carry Bartonella spp. and to circulate these pathogens in the rat population [47].

The previously reported prevalence of Bartonella spp. infection in rodents varied from $6 \%$ to $100 \%$ [18]. There are several factors related to the Bartonella prevalence rate in rodents, including habitat characteristics, body mass of rodents, age, rodent species, climate, rodent behavior, 
movement pattern, sampling method, and detection technique $[11,18,35,46,57,58]$. Additionally, varied levels of prevalence and Bartonella diversity were mentioned as common in rodents that had caused the heterogenous distribution of pathogens [59]. Even if there were no associated factor related to Bartonella infection in the studied rodents, the comparison between species of rodent and Bartonella revealed specificity. However, there was a higher infection rate in the urban area (Bangkok). Furthermore, the cool season had a higher rate of Bartonella infection than the warm season. As the preferred habitat of each rodent species differed, the detected Bartonella spp. might have been affected by characteristics of the habitat in the current study. Moreover, the size and structure of the rat population, referred to as "ecological factors", related to Bartonella prevalence and diversity, particularly in the urban environment $[56,59,60]$.

Inferring detected species, 11 of the 25 rodents carried zoonotic Bartonella spp. One R. exulans was carrying B. grahamii, which has been defined as a human pathogen and Ctenophthalamus nobilis has been suspected of being a possible vector [24]. Additionally, B. tribocorum, a zoonotic species [27], was also detected in one R. exulans. Interestingly, rodents have adapted to promote Bartonella spp. transmission to humans; in addition, Polyplax spinulosa and Xenopsylla cheopis have been mentioned as vectors of this species [27]. In other results, one $R$. tanezumi provided evidence of B. rattimassiliensis, which has also been identified as a zoonotic species carried by P. spinulosa, Haemophysalis longicornis, and Hoplopleura pacifica [61]. Bartonella phoceensis was found in both R. tanezumi and R. exulans. Bartonella phoceensis has not been reported as causing human infection, and $P$. spinulosa has been suggested as a vector carrying this non-zoonotic species [61]. Interestingly, eight of the nine $B$. tribocorum-positive $R$. exulans also matched a sequence of $B$. kosoyi with the same similarity and query coverage percentage but with differences in nucleotide substitution positions. The finding of $B$. kosoyi in R. exulans was similar to that in a study in Myanmar [55]. To date, there is no explanation of the relationship regarding glt $A$ between $B$. tribocorum and $B$. kosoyi. However, the genome of $B$. kosoyi is closely related to $B$. elizabethae [62], which has been defined as a zoonotic species of Bartonella [23]. In addition, no evidence has been reported of $B$. kosoyi infection in humans, even though it has been isolated in rodents elsewhere $[55,62,63]$.

The citrate synthase gene is widely used for Bartonella detection $[64,65]$. The citrate synthase gene was targeted for Bartonella detection in the current study, and seven haplotypes of partial gltA sequences were revealed. Several genetic events including mutation, demography, and recombination were factors regulating haplotype diversity [11]. Trimmed $g l t A$ sequences (approximately the 327 base pair) have been acclaimed for taxonomic classification in the genus Bartonella [66] and for distinguishing among subspecies and species $[2,37,65,66]$. However, an additional RNA-polymerase beta subunit $(r p o B)$ gene has been noted to increase identification efficacy, especially for the classification of new species [66]. Remarkably, glt $A$ sequencing was suggested as a common method for Bartonella diversity study in wild animals [6], although homologous recombination was an important point of this gene $[67,68]$. Compared with sequences in the NCBI database, the glt $A$ sequences of Bartonella spp. have been continuously updated, and this has facilitated more species to be distinguished $[47,65]$. Furthermore, the citrate synthase gene showed synonymous amino substitutions, and it has been emphasized that $g l t A$ was an important gene for critical functions [65]. Importantly, sequencing in the current study aimed to detect species of Bartonella using a reliable glt $A$ marker. All sequences had values of similarity percentage $>96 \%$, indicating a full match for the species, based on the recommendations from the La Scola study [66].

Unfortunately, the detection of Bartonella spp. in the ectoparasites of the captured rodents was not included in the current study. However, there should be further study of infectious ectoparasites and ectoparasites in habitat environments in order to elucidate the dynamics of Bartonella spp. circulation in rodent populations. A complete explanation of the $g l t A$ gene and haplotype requires the analysis of the whole sequence of the $g l t A$ gene of 
Bartonella. A higher-level method should be used to fill this gap in knowledge, and full gene cloning and sequencing techniques should be considered for future studies.

\section{Conclusions}

In this study, the overall prevalence was $38.57 \%$ in rodents inhabiting areas of central Thailand $(43.33 \%$ in R. exulans and $35 \%$ in R. tanezumi). Importantly, three zoonotic species were detected in the rodents' blood samples (B. tribocorum, B. grahamii in R. exulans, and $B$. rattimassiliensis in $R$. tanezumi). Furthermore, B. phoceensis was identified as the major Bartonella spp. In this rodent population. Remarkably, Bartonella phoceensis and the complex of B. tribocorum-B. kosoyi were significant in the suburban (Nakhon Sawan province) and urban (Bangkok province) areas, respectively. Comparing polymorphism in Bartonellapositive and matched reference sequences found that the complex of B. tribocorum-B. kosoyi had more differences in nucleotide sequences than B. phoceensis. Seven haplotypes of the sequences analyzed were identified; however, only haplotype A showed infection in both $R$. exulans and $R$. tanezumi. The authors suggest monitoring zoonotic species of Bartonella infection in humans, particularly in workers in contact with rodents. Furthermore, updating the knowledge on Bartonella-related diseases should be supported in risk areas.

Author Contributions: P.S.: investigation, methodology, formal analysis, and writing —original draft preparation; S.M., M.D. and S.Y.: data curation, investigation, and methodology; T.I.: conceptualization, project administration, funding acquisition, supervision, resources, and writing-review and editing. All authors have read and agreed to the published version of the manuscript.

Funding: This research was funded by the Faculty of Veterinary Medicine, Kasetsart University, Bangkok, Thailand (grant number TVP-64_03), and by the Kasetsart University Research and Development Institute (KURDI) grant number 34.60.

Institutional Review Board Statement: The study was conducted according to the guidelines of the Declaration of Helsinki, and approved by the Animal Ethics Committee of Kasetsart University, Bangkok, Thailand (approval number: ACKU63-VET048).

Informed Consent Statement: Not applicable.

Data Availability Statement: The data are contained within the article.

Acknowledgments: The authors thank the staff at the Department of Parasitology, Faculty of Veterinary Medicine, Kasetsart University, Bangkok, Thailand, for their suggestions, for providing the rodent blood samples, and for permitting access to laboratory instrument. Decha Pangjai provided the Bartonella DNA for use as a positive control from The National Institute Health, Department of Medical Science, Ministry of Public Health, Thailand.

Conflicts of Interest: The authors declare no conflict of interest in this study.

\section{References}

1. Chomel, B.B.; Boulouis, H.-J.; Maruyama, S.; Breitschwerdt, E.B. Bartonella spp. in pets and effect on human health. Emerg. Infect. Dis. 2006, 12, 389-394. [CrossRef]

2. Birtles, R.J.; Raoult, D. Comparison of partial citrate synthase gene $(g l t A)$ sequences for phylogenetic analysis of Bartonella species. Int. J. Syst. Bacteriol. 1996, 46, 891-897. [CrossRef]

3. Regier, Y.; Rourke, F.O.; Kempf, V.A.J. Bartonella spp.-A chance to establish One Health concepts in veterinary and human medicine. Parasit. Vectors 2016, 9, 261. [CrossRef]

4. Álvarez-Fernández, A.; Breitschwerdt, E.B.; Solano-Gallego, L. Bartonella infections in cats and dogs including zoonotic aspects. Parasit. Vectors 2018, 11, 624. [CrossRef]

5. De Salvo, M.N.; Hercolini, C.; Arístegui, E.; Bruno, A.; Brambati, D.F.; Cicuttin, G.L. Bartonella spp. associated with rodents in an urban protected area, Buenos Aires (Argentina). Comp. Immunol. Microbiol. Infect. Dis. 2020, 72, 101515. [CrossRef]

6. Buffet, J.-P.; Kosoy, M.; Vayssier-Taussat, M. Natural history of Bartonella-infecting rodents in light of new knowledge on genomics, diversity and evolution. Future Microbiol. 2013, 8, 1117-1128. [CrossRef]

7. S Špitalská, E.; Minichová, L.; Kocianová, E.; Škultéty, L'; Mahríková, L.; Hamšíková, Z.; Slovák, M.; Kazimírová, M. Diversity and prevalence of Bartonella species in small mammals from Slovakia, Central Europe. Parasitol. Res. 2017, 116, 3087-3095. [CrossRef]

8. Chomel, B.B.; Kasten, R.W. Bartonellosis, an increasingly recognized zoonosis. J. Appl. Microbiol. 2010, 109, 743-750. [CrossRef] [PubMed] 
9. Boularias, G.; Azzag, N.; Gandoin, C.; Bouillin, C.; Chomel, B.; Haddad, N.; Boulouis, H.J. Bartonella bovis and Bartonella chomelii infection in dairy cattle and their ectoparasites in Algeria. Comp. Immunol. Microbiol. Infect. Dis. 2020, 70, 101450. [CrossRef]

10. Cherry, N.A.; Maggi, R.G.; Cannedy, A.L.; Breitschwerdt, E.B. PCR detection of Bartonella bovis and Bartonella henselae in the blood of beef cattle. Vet. Microbiol. 2009, 135, 308-312. [CrossRef]

11. Gonçalves, L.R.; de Favacho, A.R.M.; Roque, A.L.R.; Mendes, N.S.; Fidelis, O.L., Jr.; Benevenute, J.L.; Herrera, H.M.; D'Andrea, P.S.; de Lemos, E.R.S.; Machado, R.Z.; et al. Association of Bartonella species with wild and synanthropic rodents in different Brazilian Biomes. Appl. Environ. Microbiol. 2016, 82, 7154-7164. [CrossRef]

12. Müller, A.; Gutiérrez, R.; Seguel, M.; Monti, G.; Otth, C.; Bittencourt, P.; Sepúlveda, P.; Alabí, A.; Nachum-Biala, Y.; Harrus, S. Molecular survey of Bartonella spp. in rodents and fleas from Chile. Acta Trop. 2020, 212, 105672. [CrossRef]

13. Qin, X.-R.; Liu, J.-W.; Yu, H.; Yu, X.-J. Bartonella species detected in rodents from eastern China. Vector Borne Zoonotic Dis. 2019, 19, 810-814. [CrossRef]

14. Kamani, J.; Morick, D.; Mumcuoglu, K.Y.; Harrus, S. Prevalence and diversity of Bartonella species in commensal rodents and ectoparasites from Nigeria, West Africa. PLoS Negl. Trop. Dis. 2013, 7, e2246. [CrossRef]

15. Jardine, C.; Appleyard, G.; Kosoy, M.Y.; McColl, D.; Chirino-Trejo, M.; Wobeser, G.; Leighton, F.A. Rodent-associated Bartonella in Saskatchewan, Canada. Vector Borne Zoonotic Dis. 2005, 5, 402-409. [CrossRef]

16. Dybing, N.A.; Jacobson, C.; Irwin, P.; Algar, D.; Adams, P.J. Bartonella species identified in rodent and feline hosts from island and mainland western Australia. Vector Borne Zoonotic Dis. 2016, 16, 238-244. [CrossRef]

17. Pangjai, D.; Maruyama, S.; Boonmar, S.; Kabeya, H.; Sato, S.; Nimsuphan, B.; Petkanchanapong, W.; Wootta, W.; Wangroongsarb, P.; Boonyareth, M.; et al. Prevalence of zoonotic Bartonella species among rodents and shrews in Thailand. Comp. Immunol. Microbiol. Infect. Dis. 2014, 37, 109-114. [CrossRef] [PubMed]

18. Gutiérrez, R.; Krasnov, B.; Morick, D.; Gottlieb, Y.; Khokhlova, I.S.; Harrus, S. Bartonella infection in rodents and their flea ectoparasites: An overview. Vector Borne Zoonotic Dis. 2015, 15, 27-39. [CrossRef]

19. Jiyipong, T.; Morand, S.; Jittapalapong, S.; Rolain, J.-M. Bartonella spp. infections in rodents of Cambodia, Lao PDR, and Thailand: Identifying risky habitats. Vector Borne Zoonotic Dis. 2015, 15, 48-55. [CrossRef]

20. Castle, K.T.; Kosoy, M.; Lerdthusnee, K.; Phelan, L.; Bai, Y.; Gage, K.L.; Leepitakrat, W.; Monkanna, T.; Khlaimanee, N.; Chandranoi, K.; et al. Prevalence and diversity of Bartonella in rodents of northern Thailand: A comparison with Bartonella in rodents from southern China. Am. J. Trop. Med. Hyg. 2004, 70, 429-433. [CrossRef]

21. de Favacho, A.R.M.; Andrade, M.N.; de Oliveira, R.C.; Bonvicino, C.R.; D'Andrea, P.S.; de Lemos, E.R.S. Zoonotic Bartonella species in wild rodents in the state of Mato Grosso do Sul, Brazil. Microbes Infect. 2015, 17, 889-892. [CrossRef]

22. Vayssier-Taussat, M.; Moutailler, S.; Féménia, F.; Raymond, P.; Croce, O.; La Scola, B.; Fournier, P.-E.; Raoult, D. Identification of novel zoonotic activity of Bartonella spp., France. Emerg. Infect. Dis. 2016, 22, 457-462. [CrossRef]

23. Daly, J.S.; Worthington, M.G.; Brenner, D.J.; Moss, C.W.; Hollis, D.G.; Weyant, R.S.; Steigerwalt, A.G.; Weaver, R.E.; Daneshvar, M.I.; O'Connor, S.P. Rochalimaea elizabethae sp. nov. isolated from a patient with endocarditis. J. Clin. Microbiol. 1993, 31, 872-881. [CrossRef] [PubMed]

24. Birtles, R.J.; Harrison, T.G.; Saunders, N.A.; Molyneux, D.H. Proposals to unify the genera Grahamella and Bartonella, with descriptions of Bartonella talpae comb. nov., Bartonella peromysci comb. nov., and three new species, Bartonella grahamii sp. nov., Bartonella taylorii sp. nov., and Bartonella doshiae sp. nov. Int. J. Syst. Bacteriol. 1995, 45, 1-8. [CrossRef]

25. Lin, J.-W.; Chen, C.-Y.; Chen, W.-C.; Chomel, B.B.; Chang, C.-C. Isolation of Bartonella species from rodents in Taiwan including a strain closely related to "Bartonella rochalimae" from Rattus norvegicus. J. Med. Microbiol. 2008, 57, 1496-1501. [CrossRef] [PubMed]

26. Kosoy, M.; Morway, C.; Sheff, K.W.; Bai, Y.; Colborn, J.; Chalcraft, L.; Dowell, S.F.; Peruski, L.F.; Maloney, S.A.; Baggett, H.; et al. Bartonella tamiae sp. nov., a newly recognized pathogen isolated from three human patients from Thailand. J. Clin. Microbiol. 2008, 46, 772-775. [CrossRef]

27. Heller, R.; Riegel, P.; Hansmann, Y.; Delacour, G.; Bermond, D.; Dehio, C.; Lamarque, F.; Monteil, H.; Chomel, B.; Piémont, Y. Bartonella tribocorum sp. nov., a new Bartonella species isolated from the blood of wild rats. Int. J. Syst. Bacteriol. 1998, 48 Pt 4 , 1333-1339. [CrossRef] [PubMed]

28. Welch, D.F.; Carroll, K.C.; Hofmeister, E.K.; Persing, D.H.; Robison, D.A.; Steigerwalt, A.G.; Brenner, D.J. Isolation of a new subspecies, Bartonella vinsonii subsp. arupensis, from a cattle rancher: Identity with isolates found in conjunction with Borrelia burgdorferi and Babesia microti among naturally infected mice. J. Clin. Microbiol. 1999, 37, 2598-2601. [CrossRef]

29. Kosoy, M.; Murray, M.; Gilmore, R.D.J.; Bai, Y.; Gage, K.L. Bartonella strains from ground squirrels are identical to Bartonella washoensis isolated from a human patient. J. Clin. Microbiol. 2003, 41, 645-650. [CrossRef]

30. Kosoy, M.; Bai, Y.; Sheff, K.; Morway, C.; Baggett, H.; Maloney, S.A.; Boonmar, S.; Bhengsri, S.; Dowell, S.F.; Sitdhirasdr, A.; et al. Identification of Bartonella infections in febrile human patients from Thailand and their potential animal reservoirs. Am. J. Trop. Med. Hyg. 2010, 82, 1140-1145. [CrossRef]

31. Saengsawang, P.; Kaewmongkol, G.; Inpankaew, T. Molecular Detection of Bartonella spp. and hematological evaluation in domestic cats and dogs from Bangkok, Thailand. Pathogens 2021, 10, 503. [CrossRef] [PubMed]

32. Assarasakorn, S.; Veir, J.K.; Hawley, J.R.; Brewer, M.M.; Morris, A.K.; Hill, A.E.; Lappin, M.R. Prevalence of Bartonella species, hemoplasmas, and Rickettsia felis DNA in blood and fleas of cats in Bangkok, Thailand. Res. Vet. Sci. 2012, 93, 1213-1216. [CrossRef] [PubMed] 
33. Bai, Y.; Kosoy, M.Y.; Boonmar, S.; Sawatwong, P.; Sangmaneedet, S.; Peruski, L.F. Enrichment culture and molecular identification of diverse Bartonella species in stray dogs. Vet. Microbiol. 2010, 146, 314-319. [CrossRef]

34. Saengsawang, P.; Kaewmongkol, G.; Phoosangwalthong, P.; Chimnoi, W.; Inpankaew, T. Detection of zoonotic Bartonella species in ticks and fleas parasitizing free-ranging cats and dogs residing in temples of Bangkok, Thailand. Vet. Parasitol. Reg. Stud. Rep. 2021, 25, 100612. [CrossRef]

35. Kosoy, M.; Bai, Y. Bartonella bacteria in urban rats: A movement from the jungles of Southeast Asia to metropoles around the globe. Front. Ecol. Evol. 2019, 7, 88. [CrossRef]

36. Daniel, W.W. Biostatistics: A Foundation for Analysis in the Health Sciences, 10e Student Solutions Manual; Wiley Series in Probability and Statistics; Wiley: Hoboken, NJ, USA, 2013; ISBN 9781118362228.

37. Norman, A.F.; Regnery, R.; Jameson, P.; Greene, C.; Krause, D.C. Differentiation of Bartonella-like isolates at the species level by PCR-restriction fragment length polymorphism in the citrate synthase gene. J. Clin. Microbiol. 1995, 33, 1797-1803. [CrossRef] [PubMed]

38. Brown, L.D.; Cai, T.T.; DasGupta, A. Interval estimation for a binomial proportion. Stat. Sci. 2001, 16, 101-133. [CrossRef]

39. R Core Team. R: A Language and Environment for Statistical Computing; R Core Team: Vienna, Austria, 2020.

40. Herbreteau, V.; Bordes, F.; Jittapalapong, S.; Supputamongkol, Y.; Morand, S. Rodent-borne diseases in Thailand: Targeting rodent carriers and risky habitats. Infect. Ecol. Epidemiol. 2012, 2, 18637. [CrossRef]

41. Prompiram, P.; Poltep, K.; Pamonsupornvichit, S.; Wongwadhunyoo, W.; Chamsai, T.; Rodkvamtook, W. Rickettsiae exposure related to habitats of the oriental house rat (Rattus tanezumi, Temminck, 1844) in Salaya suburb, Thailand. Int. J. Parasitol. Parasites Wildl. 2020, 13, 22-26. [CrossRef]

42. Morand, S.; Blasdell, K.; Bordes, F.; Buchy, P.; Carcy, B.; Chaisiri, K.; Chaval, Y.; Claude, J.; Cosson, J.-F.; Desquesnes, M.; et al. Changing landscapes of Southeast Asia and rodent-borne diseases: Decreased diversity but increased transmission risks. Ecol. Appl. 2019, 29, e01886. [CrossRef]

43. Billeter, S.A.; Sangmaneedet, S.; Kosakewich, R.C.; Kosoy, M.Y. Bartonella species in dogs and their ectoparasites from Khon Kaen province, Thailand. S. Asian J. Trop. Med. Public Health 2012, 43, 1186-1192. [CrossRef]

44. Malania, L.; Bai, Y.; Osikowicz, L.M.; Tsertsvadze, N.; Katsitadze, G.; Imnadze, P.; Kosoy, M. Prevalence and diversity of Bartonella species in rodents from Georgia (Caucasus). Am. J. Trop. Med. Hyg. 2016, 95, 466-471. [CrossRef] [PubMed]

45. Kerkhoff, F.T.; Bergmans, A.M.; van Der Zee, A.; Rothova, A. Demonstration of Bartonella grahamii DNA in ocular fluids of a patient with neuroretinitis. J. Clin. Microbiol. 1999, 37, 4034-4038. [CrossRef] [PubMed]

46. Blasdell, K.R.; Perera, D.; Firth, C. High prevalence of rodent-borne Bartonella spp. in urbanizing environments in Sarawak, Malaysian Borneo. Am. J. Trop. Med. Hyg. 2019, 100, 506-509. [CrossRef] [PubMed]

47. Klangthong, K.; Promsthaporn, S.; Leepitakrat, S.; Schuster, A.L.; McCardle, P.W.; Kosoy, M.; Takhampunya, R. The distribution and diversity of Bartonella species in rodents and their ectoparasites across Thailand. PLoS ONE 2015, 10, e0140856. [CrossRef]

48. Kim, K.S.; Inoue, K.; Kabeya, H.; Sato, S.; Takada, T.; Pangjai, D.; Chiu, S.-H.; Fujita, H.; Kawabata, H.; Takada, N.; et al. Prevalence and diversity of Bartonella species in wild small mammals in Asia. J. Wildl. Dis. 2016, 52, 10-21. [CrossRef]

49. Neves, E.S.; Mendenhall, I.H.; Borthwick, S.A.; Su, Y.C.F.; Smith, G.J.D. Detection and genetic characterization of diverse Bartonella genotypes in the small mammals of Singapore. Zoonoses Public Health 2018, 65, e207-e215. [CrossRef]

50. Loan, H.K.; Van Cuong, N.; Takhampunya, R.; Klangthong, K.; Osikowicz, L.; Kiet, B.T.; Campbell, J.; Bryant, J.; Promstaporn, S.; Kosoy, M.; et al. Bartonella species and trombiculid mites of rats from the Mekong Delta of Vietnam. Vector Borne Zoonotic Dis. 2015, 15, 40-47. [CrossRef] [PubMed]

51. Liu, Q.; Sun, J.; Lu, L.; Fu, G.; Ding, G.; Song, X.; Meng, F.; Wu, H.; Yang, T.; Ren, Z.; et al. Detection of Bartonella species in small mammals from Zhejiang Province, China. J. Wildl. Dis. 2010, 46, 179-185. [CrossRef]

52. Winoto, I.L.; Goethert, H.; Ibrahim, I.N.; Yuniherlina, I.; Stoops, C.; Susanti, I.; Kania, W.; Maguire, J.D.; Bangs, M.J.; Telford, S.R., 3rd; et al. Bartonella species in rodents and shrews in the greater Jakarta area. S. Asian J. Trop. Med. Public Health 2005, 36, 1523-1529.

53. Bai, Y.; Kosoy, M.Y.; Lerdthusnee, K.; Peruski, L.F.; Richardson, J.H. Prevalence and genetic heterogeneity of Bartonella strains cultured from rodents from 17 provinces in Thailand. Am. J. Trop. Med. Hyg. 2009, 81, 811-816. [CrossRef]

54. Panthawong, A.; Grieco, J.P.; Ngoen-Klan, R.; Chao, C.-C.; Chareonviriyaphap, T. Detection of Anaplasma spp. and Bartonella spp. from wild-caught rodents and their ectoparasites in Nakhon Ratchasima Province, Thailand. J. Vector Ecol. 2020, 45, 241-253. [CrossRef]

55. Böge, I.; Pfeffer, M.; Htwe, N.M.; Maw, P.P.; Sarathchandra, S.R.; Sluydts, V.; Piscitelli, A.P.; Jacob, J.; Obiegala, A. First detection of Bartonella spp. in small mammals from rice storage and processing facilities in Myanmar and Sri Lanka. Microorganisms 2021, 9 , 658. [CrossRef]

56. Peterson, A.C.; Ghersi, B.M.; Alda, F.; Firth, C.; Frye, M.J.; Bai, Y.; Osikowicz, L.M.; Riegel, C.; Lipkin, W.I.; Kosoy, M.Y.; et al. Rodent-borne Bartonella infection varies according to host species within and among cities. Ecohealth 2017, 14, 771-782. [CrossRef] [PubMed]

57. Kosoy, M.; Mandel, E.; Green, D.; Marston, E.; Childs, J. Prospective studies of Bartonella of rodents. Part I demographic and temporal patterns in population dynamics. Vector Borne Zoonotic Dis. 2004, 4, 285-295. [CrossRef]

58. Gutiérrez, R.; Vayssier-Taussat, M.; Buffet, J.-P.; Harrus, S. Guidelines for the isolation, molecular detection, and characterization of Bartonella species. Vector Borne Zoonotic Dis. 2017, 17, 42-50. [CrossRef] 
59. Himsworth, C.G.; Bai, Y.; Kosoy, M.Y.; Wood, H.; DiBernardo, A.; Lindsay, R.; Bidulka, J.; Tang, P.; Jardine, C.; Patrick, D. An investigation of Bartonella spp., Rickettsia typhi, and Seoul hantavirus in rats (Rattus spp.) from an inner-city neighborhood of Vancouver, Canada: Is pathogen presence a reflection of global and local rat population structure? Vector Borne Zoonotic Dis. 2015, 15, 21-26. [CrossRef] [PubMed]

60. Firth, C.; Bhat, M.; Firth, M.A.; Williams, S.H.; Frye, M.J.; Simmonds, P.; Conte, J.M.; Ng, J.; Garcia, J.; Bhuva, N.P.; et al. Detection of zoonotic pathogens and characterization of novel viruses carried by commensal Rattus norvegicus in New York City. MBio 2014, 5, e01933-14. [CrossRef]

61. Gundi, V.A.K.B.; Davoust, B.; Khamis, A.; Boni, M.; Raoult, D.; La Scola, B. Isolation of Bartonella rattimassiliensis sp. nov. and Bartonella phoceensis sp. nov. from European Rattus norvegicus. J. Clin. Microbiol. 2004, 42, 3816-3818. [CrossRef]

62. Gutiérrez, R.; Shalit, T.; Markus, B.; Yuan, C.; Nachum-Biala, Y.; Elad, D.; Harrus, S. Bartonella kosoyi sp. nov. and Bartonella krasnovii sp. nov., two novel species closely related to the zoonotic Bartonella elizabethae, isolated from black rats and wild desert rodent-fleas. Int. J. Syst. Evol. Microbiol. 2020, 70, 1656-1665. [CrossRef]

63. Abreu-Yanes, E.; Abreu-Acosta, N.; Izquierdo-Rodriguez, E.; Martin-Carrillo, N.; Foronda, P. Bartonella species and haplotypes in rodents and their fleas in Lanzarote and El Hierro in the Canary Islands, Spain. J. Vector Ecol. 2020, 45, 254-261. [CrossRef] [PubMed]

64. Theonest, N.O.; Carter, R.W.; Amani, N.; Doherty, S.L.; Hugho, E.; Keyyu, J.D.; Mable, B.K.; Shirima, G.M.; Tarimo, R.; Thomas, K.M.; et al. Molecular detection and genetic characterization of Bartonella species from rodents and their associated ectoparasites from northern Tanzania. PLoS ONE 2019, 14, e0223667. [CrossRef] [PubMed]

65. Kosoy, M.; McKee, C.; Albayrak, L.; Fofanov, Y. Genotyping of Bartonella bacteria and their animal hosts: Current status and perspectives. Parasitology 2018, 145, 543-562. [CrossRef]

66. Scola, B.L.; Zeaiter, Z.; Khamis, A.; Raoult, D. Gene-sequence-based criteria for species definition in bacteriology: The Bartonella paradigm. Trends Microbiol. 2003, 11, 318-321. [CrossRef]

67. Paziewska, A.; Harris, P.D.; Zwolińska, L.; Bajer, A.; Siński, E. Recombination within and between species of the alpha proteobacterium Bartonella infecting rodents. Microb. Ecol. 2011, 61, 134-145. [CrossRef]

68. Buffet, J.-P.; Pisanu, B.; Brisse, S.; Roussel, S.; Félix, B.; Halos, L.; Chapuis, J.-L.; Vayssier-Taussat, M. Deciphering Bartonella diversity, recombination, and host specificity in a rodent community. PLoS ONE 2013, 8, e68956. [CrossRef] 